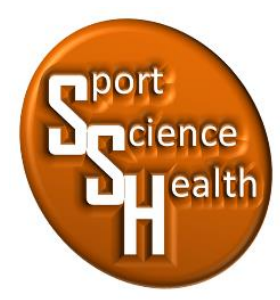

ISSN 2715-3886

\title{
Pengembangan Perangkat Pembelajaran Kebugaran Jasmani Berbasis Aplikasi Articulate Storyline
}

\author{
Mia Wirda Ardilla ${ }^{1 \star}$, Lokananta Teguh Hari Wiguno ${ }^{2}$, Ari Wibowo Kurniawan ${ }^{3}$, Mu'arifin $^{4}$ \\ 1,2,3,4 Jurusan Pendidikan Jasmani, Kesehatan dan Rekreasi, Fakultas IImu Keolahragaan, \\ Universitas Negeri Malang, Jalan Semarang No 5, Malang, Jawa Timur, 65145, Indonesia \\ *Penulis koresponden: ardillamia8@gmail.com, 081359926038
}

Artikel diterima: 5 Maret 2021; direvisi: 16 April 2021; disetujui: 21 April 2021

\begin{abstract}
Research product development aims to develop physical fitness learning tools based on the articulate storyline application for the KKG PJOK SD in Purwosari District, Pasuruan Regency. This study uses the Research and Development (R\&D) method or development research. The subjects for the small group trial involved 8 primary school Physical Education and Health teachers, and the large group trial subjects involved 26 Physical Education, Health and Sports teachers in Purwosari District. The results obtained are the percentage of learning experts $90 \%$, elementary game experts $96 \%$, PJOK experts $77 \%$, media experts $96 \%$, Physical fitness experts $78 \%$, then $91 \%$ for trial I and $89 \%$ for trial II. The conclusion in this development research is that the articulate storyline application development product is feasible to be used as a support in learning physical fitness.
\end{abstract}

Keyword: learning tools, physical fitness, articulate storyline

\begin{abstract}
Abstrak: Penelitian produk pengembangan yaitu bertujuan untuk mengembangkan perangkat pembelajaran kebugaran jasmani berbasis aplikasi articulate storyline untuk KKG PJOK SD di Kecamatan Purwosari, Kabupaten Pasuruan. Penelitian ini menggunakan metode Research and Development (R\&D) atau penelitian pengembangan. Subjek untuk uji coba kelompok kecil melibatkan 8 guru Pendidikan Jasmani Olahraga dan Kesehatan sekolah dasar, dan subjek uji coba kelompok besar melibatkan 26 guru Pendidikan Jasmani, Kesehatan dan Olahraga di Kecamatan Purwosari. Didapatkan hasil data yaitu dengan persentase ahli pembelajaran 90\%, Ahli permainan SD 96\%, Ahli PJOK 77\%, Ahli Media 96\%, Ahli Kebugaran Jasmani 78\%, kemudian $91 \%$ untuk uji coba I dan $89 \%$ untuk uji coba II. Kesimpulan dalam penelitian pengembangan ini yaitu produk pengembangan aplikasi articulate storyline ini layak untuk dipergunakan sebagai penunjang dalam pembelajaran kebugaran jasmani.
\end{abstract}

Kata kunci: perangkat pembelajaran, kebugaran jasmani, articulate storyline

\section{PENDAHULUAN}

Pendidikan Jasmani, Olahraga dan Kesehatan merupakan bagian dari kehidupan manusia, karena dengan pendidikan jasmani manusia belajar banyak hal yang berkaitan dengan kognitif, afektif, dan psikomotorik (Adi \& Fathoni, 2019, 2020a, 2020b). Pendidikan Jasmani, Olahraga dan Kesehatan juga merupakan salah satu 
pendidikan di dalam lingkup sekolah yang menggunakan aktivitas fisik dalam setiap prosesnya (Adi \& Fathoni, 2020; Fathoni, 2018). Di dalam pendidikan jasmani terdapat beberapa aspek untuk aktivitas fisik, salah satunya aspek kebugaran jasmani. Menurut Haris (2018), dalam jurnalnya menyatakan bahwa pendidikan jasmani adalah proses pendidikan yang menggunakan aktivitas jasmani untuk mencapai tujuannya yaitu untuk perkembangan fisik, perkembangan gerak, perkembangan mental, dan perkembangan sosial. Pendidikan jasmani merupakan proses dalam dunia pendidikan yang berfokus pada aktivitas pengembangan jasmani manusia (Kristiono, Dwiyogo, \& Hariadi, 2019; Masgumelar, Dwiyogo, \& Nurrochmah, 2019; Pambudi, Winarno, \& Dwiyogo, 2019; Rodriquez, Dwiyogo, \& Supriyadi, 2020). Walaupun pengembangan utama untuk mengembangan jasmani, namun tetap berorientasi pada pendidikan. Pengembangan jasmani bukan termasuk tujuan, tetapi digunakan sebagai alat untuk mencapai tujuan pendidikan (Christianto \& Dwiyogo, 2020; Dwiyogo \& Radjah, 2020; Kurniawan, Winarno, \& Dwiyogo, 2018; Manalu, Dwiyogo, \& Heynoek, 2020).

Pendidikan Jasmani, Olahraga dan Kesehatan tidak lepas akan namanya guru, guru merupakan profesi yang tugas umumnya adalah mendidik peserta didik agar berguna bagi bangsa dan negara. Khususnya untuk guru Pendidikan Jasmani, Olahraga dan Kesehatan merupakan mata pelajaran yang unik dan juga berbeda dengan materi pembelajaran yang lainnya. Dalam mata pelajaran ini guru dituntut memiliki keahlian khusus untuk memberikan materi yang diajarkan, sehingga hal tersebut dapat menjadi tantangan bagi siapapun yang berprofesi sebagai guru Pendidikan Jasmani, Olahraga dan Kesehatan.

Dalam SD (Sekolah Dasar) kebugaran jasmani merupakan materi pokok yang ada dalam pendidikan jasmani hal ini sesuai dengan Kompetensi Inti (KI) dan Kompetensi Dasar (KD) yang tertera dalam Permendikbud sebagai berikut:

Tabel 1. Kompetensi Inti dan Kompetensi Dasar Pendidikan, Jasmani, Olahraga dan Kesehatan Kelas IV Sekolah Dasar(Permendikbud, 2018)

\section{Kompetensi Inti}

\begin{tabular}{|c|c|}
\hline $\begin{array}{l}\text { Memahami pengetahuan faktual dengan } \\
\text { cara mengamati dan menanya } \\
\text { beradasarkan rasa ingin tau tentang } \\
\text { dirinya, makhluk ciptaan Tuhan dan } \\
\text { kegiatannya, dan benda-benda yang } \\
\text { dijumpainya di rumah, di sekolah dan } \\
\text { tempat bermain. }\end{array}$ & $\begin{array}{l}\text { Menyajikan pengetahuan faktual dalam } \\
\text { bahsa yang jelas, sistematis dan logis, } \\
\text { dalam karya yang estetis dalam } \\
\text { gerakan mencerminkan anak sehat, dan } \\
\text { dalam tindakan yang mencerminkan } \\
\text { perilaku anak beriman dan berakhlak } \\
\text { mulia. }\end{array}$ \\
\hline
\end{tabular}

\section{Kompetensi Dasar Kelas IV}

3.5 Memahami berbagai bentuk aktivitas kebugaran jasmani melalui berbagai latihan; daya tahan, kekuatan, kecepatan, dan kelincahan untuk mencapai berat badan ideal.

\subsection{Mempraktikkan berbagai aktivitas} kebugaran jasmani melalui berbagai bentuk latihan; daya tahan, kekuatan, kecepatan, dan kelincahan untuk mencapai berat badan ideal.

Hal tersebut dapat digunakan seorang guru pendidikan jasmani, olahraga dan kesehatan sebagai pertimbangan dalam mengembangkan pembelajaran, khusunya pada pembelajaran kebugaran jasmani. Kebugaran jasmani sangat dibutuhkan oleh siswa karena kebugaran jasmani merupakan salah satu penunjang siswa agara mampu melaksanakan suatu kegiatan-kegiatan lainnya. Menurut Sugiharto (2018) anak sekolah dasar usia 10-12 tahun merupakan merupakan usia yang kebanyakan masih cenderung menyukai permainan. Oleh karena itu, guru sekolah dasar Pendidikan Jasmani, Olahraga dan Kesehatan diharapkan mengembangkan pembelajran yang efektif untuk usia tersebut. Dengan umur tersebut merupakan masa dimana perubahan anak baik dari aspek kognitif, afektif, maupun psikomotorik. Oleh karena itu guru Pendidikan Jasmani, Olahraga dan Kesehatan harus mampu membuat pembelajaran Kebugaran Jasmani yang efektif dan menyenangkan, serta menjadikan siswa yang awalnya tidak bisa menjadi bisa, dan yang awalnya tidak tahu, menjadi tahu.

Menurut Rachmadtullah, Ms, \& Sumantri (2018), menyatakan bahwa media pembelajaran dengan berbasis komputer dapat membantu mempresentasikan materi sebagai sumber informasi tambahan yang tentunya akan memudahkan penerima atau peserta didik. Sebab itu dengan semakin berkembangnya teknologi akan 
memaksa guru untuk memanfaatkan teknologi sebagai penunjang dalam pembelajaran terutama untuk perangkat pembelajaran sepakbola aplikasi articulate storyline dan oleh sebab itu perlu adanya pendekatan, variasi, maupun modifikasi dalam setiap pembelajaran kebugaran jasmani.

Penelitian sebelumnya menurut Pratama (2018), dalam jurnalnya menyatakan bahwa aplikasi articulate storyline merupakan alat yang digunakan untuk mempresentasikan informasi dengan tujuan tertentu. Dibutuhkan kemampuan seni dan kemampuan teknis yang dikolaborasikan agar menghasilkan karya presentasi yang menarik peserta. Penelitian sebelumnya menurut Yasin (2017), dalam jurnalnya menyatakan bahwa aplikasi Articulate Storyline menawarkan beberapa template yang cukup menarik sehingga dapat dipersingkat waktu pembuatan terutama untuk membuat soal latihan maupun soal tes. Tampilan yang sederhana akan mempermudah guru dalam mengoprerasikannya. Penelitian sebelumnya menurut Darnawati, dkk (2019), dalam jurnalnya menyatakan bahwa aplikasi articulate storyline merupakan perangkat lunak yang diciptakan tahun 2014, aplikasi ini memiliki kemampuan untuk dapat menggabungkan slide, flash (swf), video dan karakter animasi menjadi satu.

Di setiap sekolah Kec. Purwosari Kab. Pasuruan yang gurunya mengikuti program KKG (Kelompok Kerja Guru) sudah memberikan materi pembelajaran kebugaran jasmani, akan tetapi dalam pemberiannya kebanyakan terlalu menoton atau kurang variasi sehingga minat siswa kebanyakan masih kurang. Kemampuan siswa dalam melakukan macam-macam kegiatan kebugaran jasmani berbeda-beda. Bisa dikatakan apabila siswa mempunyai kebugaran jasmani yang baik maka siswa tersebut dapat melaksanakan tugas suatu gerakan lainnya dengan mudah secara efektif. Wilayah Kec. Purwosari Kab. Pasuruan merupakan salah satu kecamatan yang memiliki banyak sekolah unggul dan fasilitas yang cukup memadai dan standar mulai dari lapangan olahraga, kelas, maupun halamam sekolahan. Berdasarkan hasil observasi awal yang dilakukan berupa analisis kebutuhan yang dilakukan melalui observasi dan angket dengan jumlah 30 guru KKG di Kec. Purwosari, Kab. Pasuruan, Jawa Timur diperoleh hasil 100\% guru yang pernah memeberikan materi Pendidikan Jasmani, Olahraga dan Kesehatan mengenai pembelajaran kebugaran jasmani pada peserta didik, 81,1\% guru memberikan materi kebugaran jasmani sebanyak lebih dari 2 kali dalam satu semester, $18,2 \%$ guru yang hanya menggunakan media pembelajaran dengan multimedia, $63 \%$ guru yang pernah mengunakan media pembelajaran berbasis aplikasi untuk materi kebugaran jasmani dengan media yang tercantumkan berupa pembelajaran PPT, Video dan $V C D, 77,3 \%$ guru yang sekolah tempat mengajar terdapat komputer atau laptop terdapat LCD, 90,1\% guru yang yang mampu mengoperasikan laptop atau komputer, dan terdapat $100 \%$ guru yang belum pernah melakukan pengembangan media pembelajaran berbasis aplikasi articulate storyline. Berdasarkan hasil penelitian sebelumnya terdapat beberapa keunggulan dari penelitian pengembangan peneliti yaitu dalam proses pembelajaran pendidikan jasmani, olahraga dan kesehatan tentang kebugaran jasmani unsur kecepatan dengan menggunakan program pembelajaran berbasis multimedia interaktif. Sehingga memudahkan guru dalam penyampaian materi pembelajaran dan tentunya juga memudahkan peserta didik dalam memahami materi yang disampaikan. Ditampilkan juga video untuk memperjelas peserta didik dalam memahami suatu gerakan dan juga audio agar pembelajaran tidak monoton. Terdapat juga soal-soal guna mengevaluasi seberapa jauh tingkat kepahaman peserta didik pada materi yang disampaikan. Dengan adanya produk pengembangan perangkat ini diharapkan siswa menjadi lebih aktif di dalam kelas maupun diluar dan juga bisa meningkatkan motivasi belajar siswa guna untuk mendapatkan hasil yang maksimal dalam bangku sekolah.

Berdasarkan latar belakang masalah yang telah disajikan, peneliti akan melakukan penelitian yang berjudul "Pengembangan Perangkat Pembelajaran Kebugaran Jasmani Berbasis Aplikasi Articulate Storyline Untuk Kelompok Kerja Guru (KKG) Pjok Sekolah Dasar Di Kecamatan Purwosari, Kabupaten Pasuruan”.

\section{METODE}

Model penelitian dan pengembangan per;angkat pembelajaran materi kebugaran jasssmani berbasis aplikasi Articulate Linestory menggunakan pendekatan Research and Development (R\&D) dengan menggunakan model pengembangan multimedia yang telah dikembangkan oleh Lee \& Owen (2004:93). Langkah yang dikembangkan oleh Lee \& Owen adalah langkah yang digunakan untuk memecahkan masalah dalam penelitian yang nantinya akan menghasilkan sebuah produk dari masalah penelitian tersebut. Alasan menggunakan menggunakan model yang dikemukakan oleh Lee \& Owen karena peneliti akan 
mengembangkan sebuah produk berupa perangkat pembelajaran berbasis aplikasi tentang pembelajaran kebugaran jasmani.

\section{Analisis}

Tahap ini dibagi menjadi dua bagian yaitu tahap needs assessment dan tahap front-end analysis. Needs assessment yaitu melakukan pengumpulan data secara keseluruhan dengan cara wawancara langsung dan observasi yang dapat digunakan sebagai bahan untuk mengembangkan multimedia interaktif pembelajaran kebugaran jasmani. Front-end analysis menganalisis data dan informasi yang benar-benar dibutuhkan. Pada tahap ini ada beberapa kegiatan yaitu audience analysis untuk menentukan target atau sasaran, technology analysis untuk menentukan jenis teknologi (software dan hardware) yang dibutuhkan, media analysis menentukan jenis media yang akan dikembangkan, dan extand-data analysis untuk menetapkan materi yang akan digunakan dalam aplikasi. Analisis ini merupakan langkah-langkah yang bertujuan untuk mengkaji keadaan lapangan apakah produk ini bisa diterima atau tidak oleh subjek.

\section{Desain}

Tahap desain adalah tahap perancana pengembangan perangkat pembelajaran materi kebugaran jasmani menggunakan multimedia interaktif dari informasi yang telah diperoleh dari tahap sebelumnya yaitu tahap analisis. Tahap desain meliputi material collecting (mengumpulkan bahan-bahan yang diperlukan untuk mengembangkan multimedia interaktif, pembuatan storyboard, dan pembuatan flowchart).

\section{Pengembangan}

Pada tahap ini dilakukan pengembangan perangkat multimedia interaktif mengenai pembelajaran kebugaran jasmnai sesuai desain yang telah dibuat. Terdapat beberapa tahapan yaitu, tahap pengembangan, tahap validasi, dan tahap revisi. Tahap pengembangan meliputi pengembangan interface, coding, testing, publishing, dan pemaketan. Tahap validasi dilakukan oleh ahli media, ahli pembelajaran dan ahli kebugaran jasmani untuk perbaikan produk. Revisi dilakukan bedasarkan kritik dan saran oleh para ahli agar produk bisa lebih maksimal.

\section{Implementasi}

Implementasi merupakan tahap uji coba yang dilakukan oleh peserta. Tahap ini untuk mengukur penilaian dan tanggapan terhadap pembelajaran kebugaran jasmani unsur koordinasi menggunakan multimedia interaktif yang telah dikembangkan, ditinjau dari beberapa aspek menggunakan angket penilaian.

\section{Evaluasi}

Tahap ini merupakan pengolahan nilai validasi ahli media, ahli pembelajaran, dan ahli media, serta hasil uji coba. Hal ini dilakukan untuk mengetahui tingkat kelayakan dari pembelajaran kebugaran jasmani menggunakan multimedia interaktif. Selain itu juga diberikan kekurangan, kelebihan serta spesifikasi dari produk tersebut. Tahap pengembangan dimodifikasi dan disesuaikan dengan cara yang benar dan efektif. Untuk merancang produk pengembangan ini disusun dalam bagan arus (flow chart) pada gambar berikut.

\section{Desain Uji Coba}

Pada tahap desain uji coba terdapat evaluasi yang merupakan saran dan masukan dari lima ahli yang melibatkan Ahli Pembelajaran, Ahli Permainan SD, ahli Pendidikan Jasmani, Olahraga dan Kesehatan, Ahli Media, dan Ahli Kebugaran Jasmani dan dari uji coba kelompok kecil dan kelompok besar KKG PJOK SD. Nantinya saran dan masukan dari ahli-ahli tersebut yang dipakai peneliti untuk menyempurnakan produk awal pengembangan yang sudah dirancang dan dibuat oleh peneliti.

\section{Evaluasi Ahli}

Dalam tahap evaluasi ahli ini akan melibatkan 5 ahli yaitu, (1) ahli pembelajaran yaitu, Frendy Aru Fantiro, M. Pd, (2) ahli permainan SD yaitu, Ndaru Kukuh Masgumelar, S.Pd., M.Pd, (3) ahli Pendidikan Jasmani, Olahraga dan Kesehatan yaitu, Irin Dwi Agustina, S.Pd (4) ahli media yaitu, Eka Pramono, S.I.P, M.Si. (5) ahli kebugaran jasmani yaitu, Humaid Ali Hasan, S.Pd.

\section{Uji Coba I}


Uji coba produk merupakan kegiatan uji coba tehadap rancangan produk dengan subjek guru PJOK SD yang diwakili oleh 8 orang guru PJOK SD.

\section{Uji Coba II}

Uji coba II adalah uji coba produk produk terakhir yang akan dilakukan dengan subjek 26 guru PJOK SD.

\section{Subyek Uji Coba}

Subjek penelitian dan pengembangan ini adalah 34 guru Pendidikan Jasmani, Olahraga dan Kesehatan Kecamatan Purwosari, Kabupaten Pasuruan.

\section{Jenis Data}

Jenis data yang dipakai dalam proses pengamatan pembelajaran adalah jenis data kuantitatif dan kualitatif. Kuantitatif merupakan data yang didalamnya berupa angka sedangkan kualitatif merupakan data yang berisi saran dan paparan. Data kuantitatif diperoleh dari hasil tes uji coba 1. Data kualitatif diperoleh dari hasil wawancara terhadap guru Pendidikan Jasmani, Olahraga, dan Kesehatan dan evaluasi dari para ahli.

\section{Instrumen Pengumpulan Data}

Instrumen pengumpulan data yang digunakan dalam penelitian ini menggunakan metode angket. Angket digunakan untuk mendapatkan data dari para ahli diantaranya ahli permainan, ahli media, ahli pembelajaran, serta data uji coba. Bentuk pengumpulan angket dari setiap ahli berbeda, diantaranya data tentang evaluasi berupa masukan, kritik, komentar, dan saran dari para ahli. Selain itu Pasuruan.

\section{Teknik Analisis Data}

Teknik analisis data yang digunakan dalam penelitian ini menggunakan teknik analisis statistik deskriptif. Teknik yang digunakan dalam pengukuran ini menggunakan skala Likert. Hal ini digunakan untuk megukur sikap, pendapat, dan persepsi tiap orang atau kelompok tentang keadaan tertentu Sugiyono (2017:134) Jawaban dari setiap poin skala likert mempunyai ukuran dari sangat positif sampai sangat neagtif. Jawaban diberi skor yang telah dijadikan tolak ukur yaitu satu, dua, tiga, empat, hal ini dilakukan untuk keperluan analisis kuantitatif. Skala penilaian bisa dilihat pada table berikut.

Tabel 2. Skala Evaluasi Pernyataan

\begin{tabular}{clcc}
\hline No & Kategori & Pilihan & Skor \\
\hline 1. & Sangat Setuju & A & 4 \\
2. & Setuju & B & 3 \\
3. & Ragu-ragu & C & 2 \\
4. & Tidak Setuju & D & 1 \\
\hline
\end{tabular}

Rumus dalam mendapatkan data berbentuk deskriptif kuantitatif dengan persentase yang dikatakan Akbar \& Sriwiyana, di bawah ini:

$$
\mathrm{V}=\frac{\mathrm{TSEV}}{\mathrm{S}-\max } \times 100 \%
$$

\section{Keterangan:}

V : Validitas

TSEV : Total skor empirik validator

S-max : Skor maksimal yang diharapkan

$100 \%$ : Bilangan konstanta

Kemudian sebagai memudahkan pada bagian ketepatan data hasil menganalisis persentase dapat dikaitkan pada persentase yang telah didapatkan. Penggolongan kategorisasi persentase yaitu: 
Tabel 3. Parameter Status Produk (Irawan \& Japarianto, 2013)

\begin{tabular}{lll}
\hline persentase & Kategori & Arti \\
\hline $75,01 \%-100,00 \%$ & Sangat Valid & Dapat dipakai tanpa revisi \\
$50,01 \%-75,00 \%$ & Cukup Valid & Dapat dipakai dengan revisi \\
$25,01 \%-50,00 \%$ & Tidak Valid & Tidak dapat dipakai \\
$00,00 \%-25,00 \%$ & Sangat Tidak Valid & Terlarang dipakai \\
\hline
\end{tabular}

HASIL

Pembahasan kali ini tentang produk pengembangan, penyajian data yang terdiri dari analisis kebutuhan, validasi para ahli, uji coba produk kelompok kecil, dan uji coba produk kelompok besar, serta revisi produk.

\section{Ahli Pembelajaran}

Tabel 4. Hasil Analisis Data Ahli Pembelajaran

\begin{tabular}{clccc}
\hline No & & Aspek & $\%$ & Kategori \\
\hline 1 & Kejelasan & & 86 & Sangat Valid \\
2 & Ketepatan & & 83 & Sangat Valid \\
3 & Kemudahan & & 100 & Sangat Valid \\
\hline & & rata-rata & 90 & Sangat Valid \\
\hline
\end{tabular}

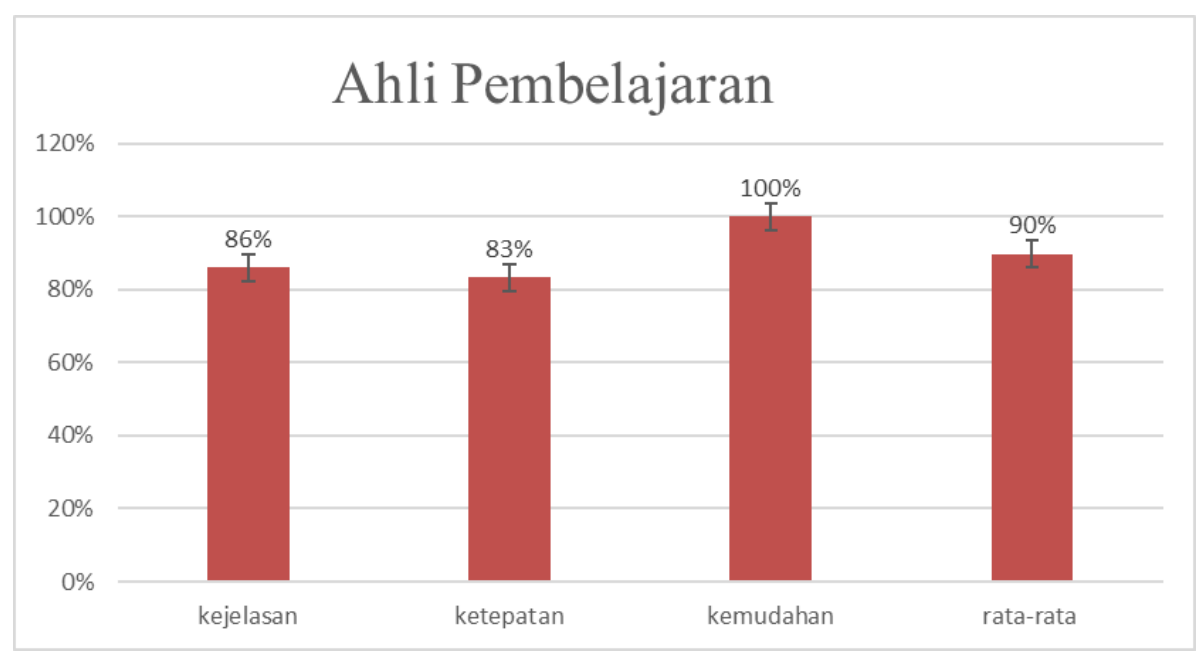

Gambar 1. Diagram Penilaian Ahli Pembelajaran

Berdasarkan hasil analisis data yang diperoleh dari uji validasi oleh ahli pembelajaran dengan persentase sebesar $90 \%$, hasil tersebut didapatkan dari beberapa aspek kemudian hasil tersebut dikonversikan berdasarkan tabel klasifikasi kelayakan menunjukkan bahwa produk pengembangan perangkat pembelajaran kebugaran jasmani berbasis aplikasi articulate storyline telah memenuhi kriteria sangat valid dan layak digunakan untuk melanjutkan uji coba kelompok.

\section{Ahli Permainan SD}

Tabel 5. Hasil Analisis Data Ahli Permainan SD

\begin{tabular}{clccc}
\hline N0 & & Aspek & $\%$ & Kategori \\
\hline 1 & Kejelasan & & 95 & Sangat Valid \\
2 & Ketepatan & & 83 & Sangat Valid \\
3 & Kemudahan & & 100 & Sangat Valid \\
4 & Kemenarikan & 100 & Sangat Valid \\
5 & Kesesuaian & & 100 & Sangat Valid \\
\hline & & 96 & Sangat Valid \\
\hline
\end{tabular}




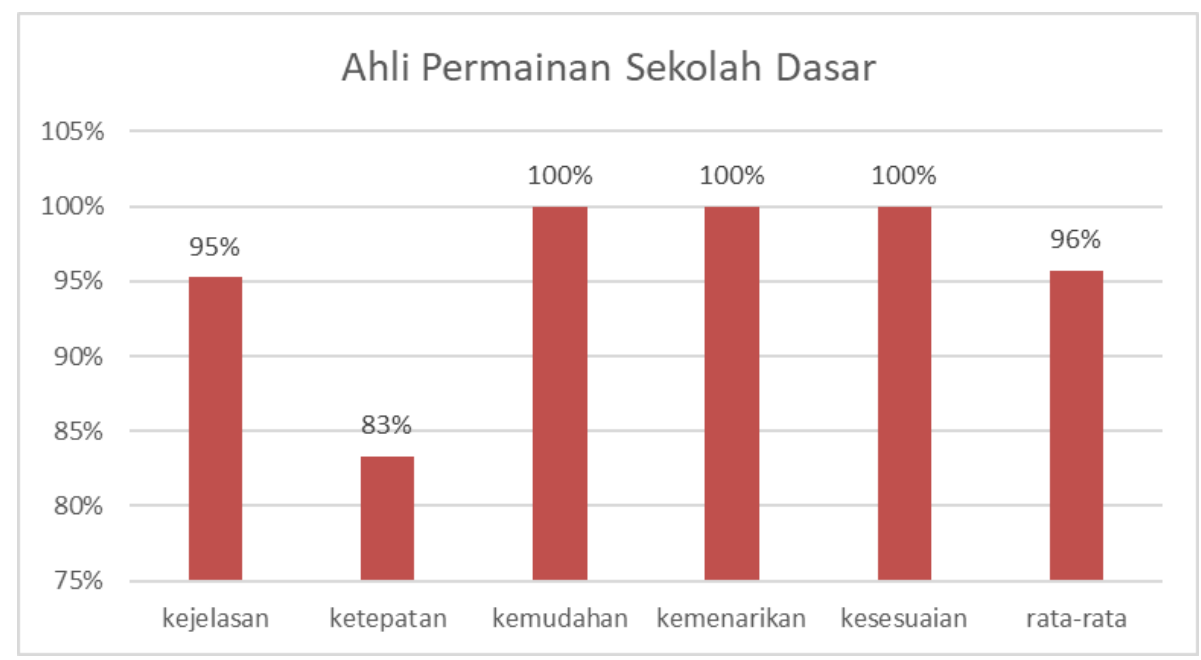

Gambar 2. Diagram Penilaian Ahli Permainan Sekolah Dasar

Berdasarkan hasil analisis data yang diperoleh dari uji validasi oleh ahli Permainan Sekolah Dasar dengan persentase sebesar 96\%, hasil tersebut didapatkan dari beberapa aspek kemudian hasil tersebut dikonversikan berdasarkan tabel klasifikasi kelayakan menunjukkan bahwa produk pengembangan perangkat pembelajaran kebugaran jasmani berbasis aplikasi articulate storyline telah memenuhi kriteria sangat valid dan layak digunakan untuk melanjutkan uji coba kelompok.

\section{Ahli Pendidikan Jasmani, Olahraga dan Kesehatan}

Tabel 6. Hasil Analisis Data Ahli Pendidikan Jasmani Olahraga dan Kesehatan

\begin{tabular}{cllcc}
\hline N0 & & Aspek & $\%$ & Kategori \\
\hline 1 & Kejelasan & 83 & Sangat Valid \\
2 & Ketepatan & 75 & Cukup Valid \\
3 & Kemudahan & 75 & Cukup Valid \\
4 & Kemenarikan & 75 & Cukup Valid \\
5 & Kesesuaian & & 75 & Cukup Valid \\
\hline & & rata-rata & 77 & Sangat Valid
\end{tabular}

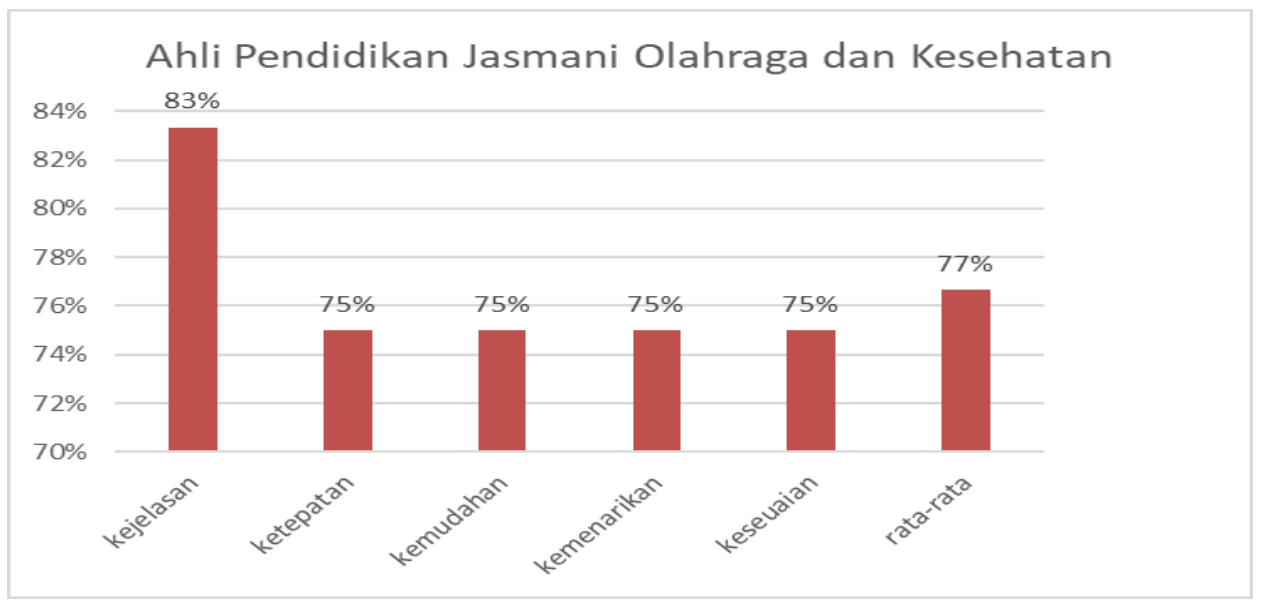

Gambar 3. Diagram Penilaian Ahli Pendidikan Jasmani dan Kesehatan

Berdasarkan hasil analisis data yang diperoleh dari uji validasi oleh ahli Pendidikan Jasmani Olahraga dan Kesehatan dengan persentase sebesar $77 \%$, hasil tersebut didapatkan dari beberapa aspek kemudian hasil tersebut dikonversikan berdasarkan tabel klasifikasi kelayakan menunjukkan bahwa produk pengembangan perangkat pembelajaran kebugaran jasmani berbasis aplikasi articulate storyline telah memenuhi kriteria sangat valid dan layak digunakan untuk melanjutkan uji coba kelompok. 


\section{Ahli Media}

Tabel 7. Hasil Analisis Data Ahli Media

\begin{tabular}{clccc}
\hline N0 & & Aspek & $\%$ & Kategori \\
\hline 1 & Kejelasan & & 92 & Sangat Valid \\
2 & Ketepatan & & 100 & Sangat Valid \\
3 & Kemudahan & 100 & Sangat Valid \\
4 & Kemenarikan & 86 & Sangat Valid \\
5 & Kesesuaian & 98 & Sangat Valid \\
6 & Kelengkapan & & 100 & Sangat Valid \\
\hline & & 96 & Sangat Valid \\
\hline
\end{tabular}

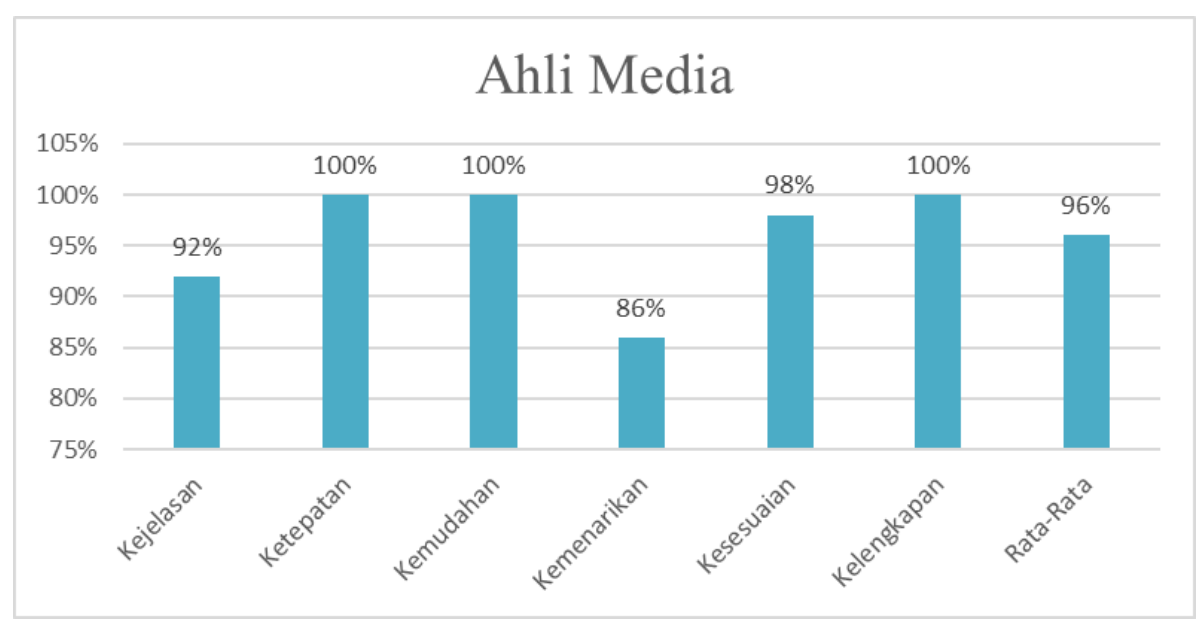

Gambar 4. Diagram Penilaian Ahli Media

Berdasarkan hasil analisis data yang diperoleh dari uji validasi oleh ahli media dengan persentase sebesar $96 \%$, hasil tersebut didapatkan dari beberapa aspek kemudian hasil tersebut dikonversikan berdasarkan tabel klasifikasi kelayakan menunjukkan bahwa produk pengembangan perangkat pembelajaran kebugaran jasmani berbasis aplikasi articulate storyline telah memenuhi kriteria sangat valid dan layak digunakan untuk melanjutkan uji coba kelompok.

\section{Ahli Kebugaran Jasmani}

Tabel 8. Hasil Analisis Data Kebugaran Jasmani

\begin{tabular}{clccc}
\hline N0 & & Aspek & $\%$ & Kategori \\
\hline 1 & Kejelasan & & 88 & Sangat Valid \\
2 & Ketepatan & 75 & Sangat Valid \\
3 & Kemudahan & & 75 & Sangat Valid \\
4 & Kemenarikan & 75 & Sangat Valid \\
5 & Kesesuaian & & 75 & Sangat Valid \\
\hline & & 78 & Sangat Valid \\
\hline
\end{tabular}




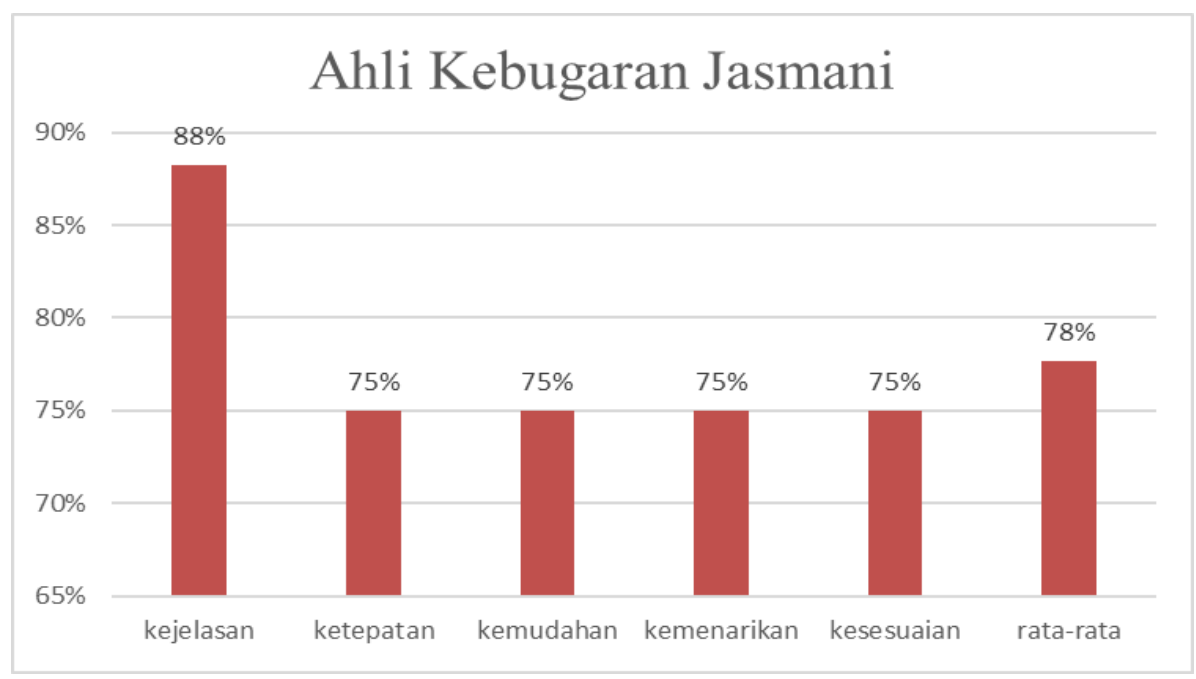

Gambar 5. Diagram Penilaian Ahli Kebugaran Jasmani

Berdasarkan hasil analisis data yang diperoleh dari uji validasi oleh ahli kebugaran jasmani dengan persentase sebesar $78 \%$, hasil tersebut didapatkan dari beberapa aspek kemudian hasil tersebut dikonversikan berdasarkan tabel klasifikasi kelayakan menunjukkan bahwa produk pengembangan perangkat pembelajaran kebugaran jasmani berbasis aplikasi articulate storyline telah memenuhi kriteria sangat valid dan layak digunakan untuk melanjutkan uji coba kelompok.

\section{Uji Coba Kelompok Kecil}

Tabel 9. Hasil Analisis Data Uji Coba Kelompok Kecil Kelompok Kerja Guru PJOK

\begin{tabular}{clcl}
\hline No. & \multicolumn{1}{c}{ Aspek } & $\%$ & Kategori \\
\hline 1 & Kejelasan & 92 & Sangat Valid \\
2 & Kegunaan & 89 & Sangat Valid \\
3 & Kemudahan & 89 & Sangat Valid \\
4 & Kemenarikan & 91 & Sangat Valid \\
5 & Kesesuaian & 90 & Sangat Valid \\
\hline \multicolumn{2}{r}{ Rata-Rata } & $\mathbf{9 0}$ & Sangat Valid \\
\hline
\end{tabular}

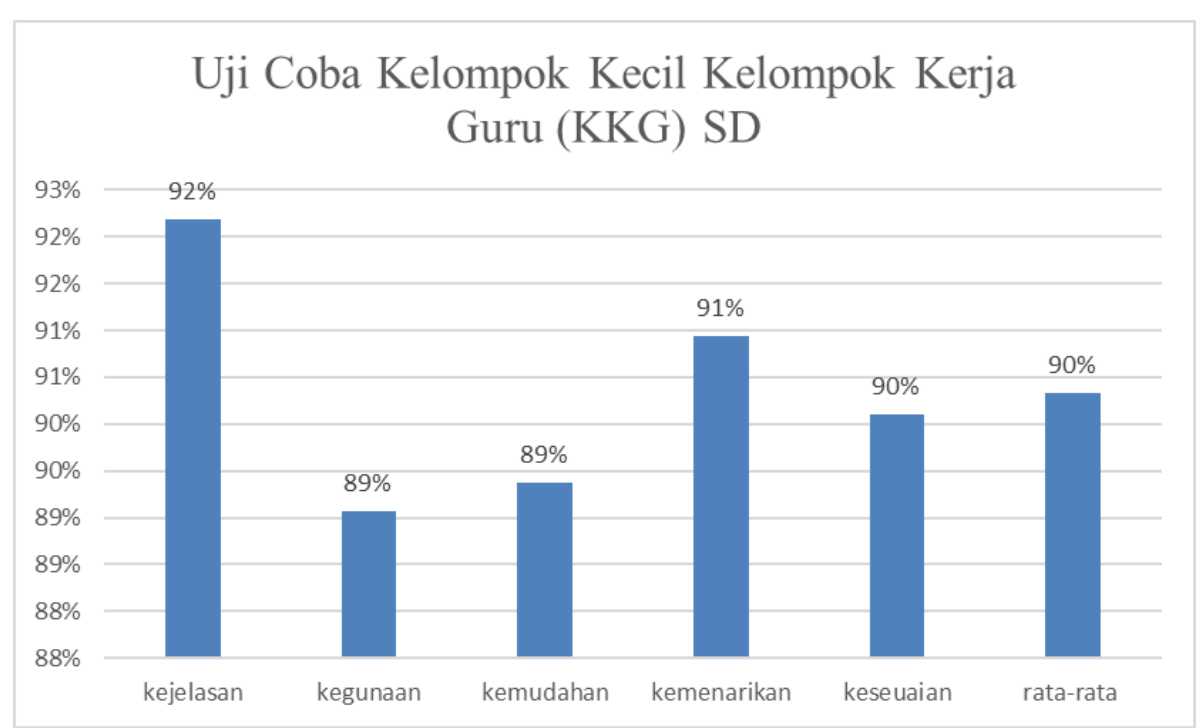

Gambar 6. Diagram Penilaian Analisis Data Uji Coba Kelompok Kecil Kelompok

Berdasarkan hasil analisis data yang diperoleh dari uji coba kelompok kecil oleh Kelompok Kerja Guru (KKG) PJOK SD di Kecamatan Purwosari, Kabupaten Pasuruan dengan persentase sebesar $90 \%$, hasil tersebut didapatkan berdasarkan aspek-aspek kemudian hasil tersebut dikonversikan berdasarkan tabel 
klasifikasi kelayakan menunjukkan bahwa produk pengembangan perangkat pembelajaran kebugaran jasmani berbasis aplikasi articulate storyline telah memenuhi kriteria sangat valid dan layak digunakan.

\section{Uji Coba Kelompok Besar}

Tabel 10. Hasil Analisis Data Uji Coba Kelompok Besar Kelompok Kerja Guru (KKG) PJOK SD

\begin{tabular}{clcl}
\hline No. & \multicolumn{1}{c}{ Aspek } & $\%$ & Kategori \\
\hline 1 & Kejelasan & 89 & Sangat Valid \\
2 & Kegunaan & 94 & Sangat Valid \\
3 & Kemudahan & 88 & Sangat Valid \\
4 & Kemenarikan & 90 & Sangat Valid \\
5 & Kesesuaian & 89 & Sangat Valid \\
\hline & Rata-Rata & $\mathbf{9 0}$ & Sangat Valid
\end{tabular}

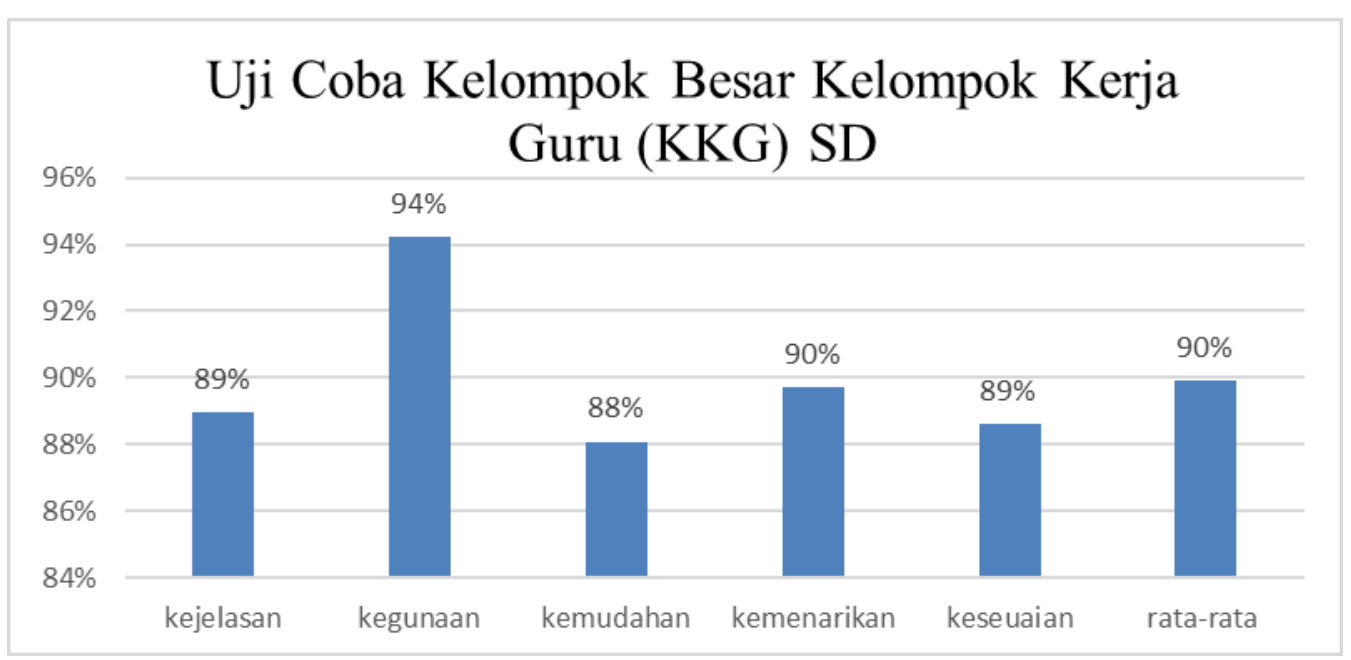

Gambar 7. Diagram Penilaian Analisis Data Uji Coba Kelompok Kecil Kelompok

Berdasarkan hasil analisis data yang diperoleh dari uji coba kelompok besar oleh Kelompok Kerja Guru (KKG) PJOK SD di Kecamatan Purwosari, Kabupaten Pasuruan dengan persentase sebesar 90\%, hasil tersebut didapatkan berdasarkan aspek-aspek kemudian hasil tersebut dikonversikan berdasarkan tabel klasifikasi kelayakan menunjukkan bahwa produk pengembangan perangkat pembelajaran kebugaran jasmani berbasis aplikasi articulate storyline telah memenuhi kriteria sangat valid dan layak digunakan.

\section{PEMBAHASAN}

Produk yang dihasilkan peneliti ini adalah produk pengembangan perangkat pembelajaran kebugaran jasmani yang mana dijadikan dan dikembangkan kedalam aplikasi berbasis aplikasi articulate storyline yang menjadikan satu beberapa komponen dari gambar, teks, video maupun suara, mulai dari RPP, bahan ajar maupun evaluasi. Sependapat dengan Purnama \& Asto (2014) bahwasannya aplikasi articulate storyline merupakan suatu perangkat lunak yang dipergunakan untuk suatu media komunikasi atau sebagai penyambung maupun perantara pada saat pelaksanaan penyampaian materi dengan fitur-fitur untuk dapat memasukkan gambar, video, suara dan juga teks yang nantinya akan mampu diakses atau di aplikasikan baik offline maupun online.

Produk pengembangan perangkat jasmani ini dijadikan suatu aplikasi articulate storyline yang mana berisikan rancangan pelaksanaan pembelajaran, bahan ajar mulai dari pengertian tata cara pelaksanaan, sapras saat kegiatan dan evaluasii yang dimasukkan kedalam materi pembelajaran khususnya kelas 4 SD. Seperti yang disampaikan oleh Uno \& Lamatenggo yang mana menyebutkan bahwasannya media pembelajaran adalah suatu bentuk yang bisa dipergunakan untuk penyampaian informasi dari sumber untuk penerima yaitu peserta duduk dengan sangat mudah dan juga mampu untuk merangsang peserta didik dalam proses mengikuti pembelajaran secara untuh ataupun sebagian tertentu. 
Produk penelitian dan pengembangan ini adalah produk pengembangan perangkat pembelajaran sepakbola berbasis aplikasi articulate storyline yang menyatukan gambar, tulisan, video, dan suara yang dikemas menjadi aplikasi. Seperti halnya menurut pendapat Setyaningsih, Rusijono, \& Wahyudi (2020), menyatakan bahwa hasil belajar kelas yang menggunakan media pembelajaran articulate storyline mata pelajaran IPS meningkat $70 \%$ dari pada kelas yang belum memakai media pendukung. Penggunaan media sebagai sarana pembelajaran di sekolah bertujuan untuk siswa lebih mudah dalam memahami materi. Sehingga nantinya tujuan dalam kompetensi pembelajaran dapat dicapai, hal tersebut selaras dengan Larsson \& Karlefors, (2015), dalam jurnalnya yang mengemukakan bahwa guru bukan satu-satunya sumber belajar, sebab menjadi seorang guru harus memiliki strategi pembelajaran yang akan membantu siswa untuk memahami kegiatan pendidikan salah satunya mengembangkan media pembelajaran. Penelitian sebelumnya menurut Leow \& Neo (2014), dalam jurnalnya yang menyatakan bahwa pembelajaran yang kreatif salah satunya dengan memanfaatkan konten media yang melibatkan siswa, tanpa disadari akan meningkatkan motivasi siswa dalam proses pembelajaran yang tentunya akan berpengaruh pada hasil belajar siswa. Selaras dengan pendapat tersebut penelitian sebelumnya menurut Rahman, Kurniawan, \& Heynoek, (2020), menyatakan bahwa hasil penelitian menunjukkan bahwa produk pembelajaran kebugaran jasmani unsur kecepatan di SMA Negeri 1 Turen Layak digunakan dalam pembelajaran dan sebagai referensi sember belajar terutama mata pelajaran pendidikan jasmani kesehatan dan olahraga kelas X dan XI. Siswa lebih aktif dan sangat antusias dalam mengikuti pelajaran dalam materi kebugaran jasmani unsur kecepatan dengan menggunakan multimedia interaktif. Selaras menurut Pamungkas, I. A. \& Dwiyogo, W. D (2020), menyatakan bahwa penelitian menghasilkan produk pengembangan media pembelajaran berbasis mobile learning untuk aktifitas kesegaran jasmani siswa SMKN 1 Batu. Adapun hasil dari penelitian menunjukan nilai yang maksimal atau indeks Amat Baik, sehingga dapat disimpulkan pengembangan media pembelajaran Kebugaran jasmani sangat valid untuk digunakan untuk guru kelas, siswa, pelatih dan khalayak luas yang ingin mempelajari kebugaran jasmani. Sehingga aplikasi articulate storyline ini tergolong dalam perangkat pembelajaran yang efisien dimana produk ini berupa aplikasi android yang dapat diakses dengan mudah serta dapat digunakan sebelum pembelajaran di lapangan. Kemudian pada aplikasi articulate storyline ini berisi rencana pelaksanaan pembelajaran kebugaran jasmani kelas IV, materi pembelajaran kelas IV meliputi: pengertian kebugaran jasmani, sarana dan prasarana kebugaran jasmani, teknik dasar dalam permainan, serta video pembelajaran materi kelas IV, terdapat evaluasi penilaian untuk kelas IV, dan biodata penulis.

Diciptakannya pengembangan ini sebagai media bagi bapak maupun ibu guru dalam hal penyampaian informasi ataupun pembelajaran kepada peserta didik khususnya kelas 4 SD materi kebugaran jasmani yang nantinya bisa dijadikan referensi bagi bapak atau ibu guru.

\section{Revisi Produk}

Berdasarkan data evaluasi tinjauan dari beberapa ahli yang meliputi ahli pembelajaran, ahli permainan sekolah dasar, ahli pendidikan jasmani, olahraga dan kesehatan, ahli media, ahli kebugaran jasmani dan hasil uji coba kelompok kecil dan coba kelompok besar, bertujuan untuk menyempurnakan produk pengembangan perangkat pembelajaran kebugaran jasmani berbasis aplikasi articulate storyline untuk Kelompok Kerja Guru (KKG) di Kecamatan Purwosari, Kabupaten Pasuruan terdapat beberapa revisi yang bertujuan agar produk yang dikembangkan ini semakin baik, saran dan masukan disajikan pada Tabel 11 berikut: 
Tabel 11. Data Saran dan Masukan Produk pengembangan perangkat pembelajaran kebugran jasmani berbasis aplikasi articulate storyline untuk Kelompok Kerja Guru (KKG)

\begin{tabular}{|c|c|c|}
\hline No & Penilaian dan Saran & Keterangan \\
\hline \multirow[t]{4}{*}{1} & Ahli Pembelajaran & \\
\hline & 1. Font tidak dibut terlalu kaku & Sudah \\
\hline & 2. Menambahkan video pembelajaran & direvisi \\
\hline & 3. Menambahkan video pemanasan dinamis & \\
\hline \multirow[t]{3}{*}{2} & Ahli Permainan Sekolah Dasar & \\
\hline & 1. Buat gerakan-gerakan yang aman & Sudah \\
\hline & 2. Sertakan alasan mengapa mimilih 4 unsur & \\
\hline \multirow[t]{3}{*}{3} & Ahli Pendidikan Jasmani, Olahraga dan Kesehatan & \\
\hline & 1. Beri tulisan pada video pembelajaran & Sudah \\
\hline & 2. Tambahkan $\mathrm{KI}$ dan $\mathrm{KD}$ & \\
\hline \multirow[t]{4}{*}{4} & Ahli Media & \\
\hline & 1. Tambah daftar pustaka jika mengutip dari sumber & Sudah \\
\hline & lain & direvisi \\
\hline & 2. Beri gambar pada button agar lebih menarik & \\
\hline \multirow[t]{4}{*}{5} & Ahli Kebugaran Jasmani & \\
\hline & 1. Sarana dan prasarana diberikan gambar & Sudah \\
\hline & 2. Pengulangan dalam melaksanakan kegiatan & direvisi \\
\hline & 3. Modifikasi permainan & \\
\hline \multirow[t]{3}{*}{6} & Uji Coba & \\
\hline & 1. Instrument musik yang lebih bersemangat & direvisi \\
\hline & 2. Tampilan video terdapat icon stop & \\
\hline
\end{tabular}

\section{KESIMPULAN}

Hasil pengembangan dan penelitian produk pembelajaran kebugaran jasmani berbasis aplikasi articulate storyline yang dilakukan, maka dapat disimpulkan bahwa produk pengembangan kebugaran jasmani berbasis aplikasi articulate storyline layak digunakan dalam pembelajaran kebugaran jasmani kelas IV dan dapat dijadikan sebagai penunjang pembelajaran pada mata pelajaran pendidikan jasmani, olahraga dan kesehatan pada kelas IV terutama pada materi pembelajaran kebugaran jasmani.

\section{DAFTAR PUSTAKA}

Adi, S., \& Fathoni, A. F. (2019). Development of Learning Model Based on Blended Learning in Sports School. https://doi.org/10.2991/acpes-19.2019.2

Adi, S., \& Fathoni, A. F. (2020). Blended Learning Analysis for Sports Schools in Indonesia. International Journal of Interactive Mobile Technologies (iJIM), 14(12), 149-164. Retrieved from https://www.onlinejournals.org/index.php/i-jim/index

Adi, S., \& Fathoni, A. F. (2020). Mobile Learning sebagai Fasilitas Belajar Mandiri Pembelajaran Senam Lantai pada Mahasiswa Jurusan IImu Keolahragaan. Jurnal Pendidikan: Teori, Penelitian, Dan Pengembangan, 5(8), 1158-1166. Retrieved from http://journal.um.ac.id/index.php/jptpp/article/view/13946/6206

Adi, S., \& Fathoni, A. F. (2020). The effectiveness and efficiency of blended learning at sport schools in Indonesia. International Journal of Innovation, Creativity and Change.

Akhmad. 2016. Sumber Belajar Penunjang PLPG 2016.

Christianto, J., \& Dwiyogo, W. D. (2020). PENGEMBANGAN MEDIA PEMBELAJARAN CRICKET BERBASIS MOBILE LEARNING PADA TIM OLAHRAGA CRICKET UNIVERSITAS NEGERI MALANG. Gelanggang Pendidikan Jasmani Indonesia, 3(2), 168. https://doi.org/10.17977/um040v3i2p168-174 
Darnawati, Jamiludin, Batia, L., Irawaty, \& Salim. (2019). Pemberdayaan Guru Melalui Pengembangan Multimedia Pembelajaran Interaktif Dengan Aplikasi Articulate Storyline. Jurnal Pengabdian Kepada Masyarakat, 1(1), 8-16.

Dwiyogo, W. D., \& Radjah, C. L. (2020). Effectiveness, efficiency and instruction appeal of blended learning model. International Journal of Online and Biomedical Engineering, 16(4), 91-108. https://doi.org/10.3991/ijoe.v16i04.13389

Fathoni, A. F. (2018). The Role of Blended Learning on Cognitive Step in Education of Sport Teaching by Adjusting the Learning Style of the Students. https://doi.org/10.2991/isphe-18.2018.49

Haris, I. N. (2018). Model Pembelajaran Peer Teaching Dalam Pembelajaran Pendidikan Jasmani. Jurnal IImiah Fkip Universitas Subang, 4(1), 2461-3961.

Irawan, D. \& Japarianto, E. (2013). Analisa Pengaruh Kualitas Produk Terhadap Loyalitas Melalui Kepuasan Sebagai Variabel Intervening Pada Pelanggan Restoran Por Kee Surabaya. Jurnal Manajemen Pemasaran.

Kristiono, I. D., Dwiyogo, W. D., \& Hariadi, I. (2019). Pembelajaran IImu Gizi Olahraga Berbasis Blended Learning pada Mahasiswa Pendidikan Jasmani, Kesehatan, dan Rekreasi. Jurnal Pendidikan: Teori, Penelitian, Dan Pengembangan, 4(2), 235-241. Retrieved from http://journal.um.ac.id/index.php/jptpp/article/view/12004

Kurniawan, A.W.,\& Tangkudung, J. (2017). Development Of Interactive Multimedia-Based Gymnastics Floor Techniques Learning Model For Junior High School Students. Journal Of Indonesian Physical Education And Sport 3(1), 100-115.

Kurniawan, A. W. 2019. Multimedia-Based Learning Model for Gymnastics Skills, 7(Icssh 2018), 33-36.

Kurniawan, R., Winarno, M. E., \& Dwiyogo, W. D. (2018). Evaluasi Pembelajaran Pendidikan Jasmani, Olahraga, dan Kesehatan pada Siswa SMA Menggunakan Model Countenance. Jurnal Pendidikan: Teori, Penelitian, Dan Pengembangan, 3(10), 1-12. Retrieved from http://journal.um.ac.id/index.php/jptpp/article/view/11599

Larsson, H., \& Karlefors, I. (2015). Physical education cultures in Sweden : fitness, sports , dancing learning. Sport, Education and Society, 20(5), 573-587.

Leow, F.-T., \& Neo, M. (2014). Interactive Multimedia Learning: Innovating Classroom Education In A Malaysian University. The Turkish Online Journal of Educational Technology, 13(2), 99-110.

Manalu, D. L., Dwiyogo, W. D., \& Heynoek, F. P. (2020). Pengembangan Multimedia Interaktif Latihan Kekuatan Pada Matakuliah Spesialisasi Kondisi Fisik Dasar Untuk Mahasiswa Pendidikan Kepelatihan Olahraga Fakultas IImu Keolahragaan. Sport Science and Health, 2(1), 49-57. Retrieved from http://journal2.um.ac.id/index.php/jik/article/view/11158

Masgumelar, N. K., Dwiyogo, W. D., \& Nurrochmah, S. (2019). Modifikasi Permainan menggunakan Blended Learning Mata Pelajaran Pendidikan Jasmani, Olahraga, dan Kesehatan. Jurnal Pendidikan: Teori, Penelitian, Dan Pengembagan, 4(7), 979-986. Retrieved from http://journal.um.ac.id/index.php/jptpp/article/view/12645

Nurrochmah, S. 2016. Tes dan Pengukuran Dalam Pendidikan Jasmani dan Keolahraga. Malang: Universitas Negeri Malang (UM PRESS).

Pambudi, M. I., Winarno, M., \& Dwiyogo, W. D. (2019). Perencanaan dan Pelaksanaan Pembelajaran Pendidikan Jasmani Olahraga Kesehatan. Jurnal Pendidikan Olahraga, Universitas Negeri Malang, 4(1), 110-116. Retrieved from http://journal.um.ac.id/index.php/jptpp/

Pamungkas, I. A., \& Dwiyogo, W. D. (2020). Pengembangan Media Pembelajaran Berbasis Mobile Learning Untuk Aktifitas Kesegaran Jasmani Siswa kelas X Sekolah Menengah Kejuruhan. Sport Science and Health, 2(5), 272-278

Pratama, R. A. (2018). Media Pembelajaran Berbasis Articulate Storyline 2 Pada Materi Menggambar Grafik Fungsi Di Smp Patra Dharma 2 Balikpapan Learning Media Based On Articulate Storyline 2 On Drawing 
Function Graphs Lesson In SMP Patra Dharma 2 Balikpapan. Jurnal Dimensi, 7(1), 19-35.

Permendikbud. (2016). Tentang Kompetensi Inti dan Kompetensi Dasar Pada Kurikulum 2013 Pada Pendidikan Dasar Dan Pendidikan Menengah. Jakarta: Permendikbud.

Purnama, S., \& Asto B, I. G. P. (2014). Pengembangan Media Pembelajaran Interaktif Menggunakan Software Articulate Storyline Pada Mata Pelajaran Teknik Elektronika Dasar Kelas X TEI 1 Di SMK Negeri 2 Probolinggo. Jurnal Pendidikan Teknik Elektro, 3(2), 275-279.

Rachmadtullah, R., Ms, Z., \& Sumantri, M. S. (2018). Development of computer - based interactive multimedia : study on learning in elementary education. International Journal of Engineering \& Technology, 7(4), 2051-2054.

Rahman, Z., Kurniawan, A. W., \& Heynoek, F. P. (2020). Pengembangan Pembelajaran Kebugaran Jasmani Unsur Kecepatan Berbasis Multimedia Interaktif. Sport Science and Health, 2(1), 78-92.

Rodriquez, E. I. S., Dwiyogo, W. D., \& Supriyadi. (2020). Blended Learning Matakuliah Sepakbola untuk Mahasiswa Pendidikan Jasmani Kesehatan dan Rekreasi. Jurnal Pendidikan: Teori, Penelitian, Dan Pengembagan, 5(2), 206-213.

Setyaningsih, S., Rusijono, \& Wahyudi, A. (2020). Pengaruh Penggunaan Media Pembelajaran Interaktif Berbasis Articulate Storyline Terhadap Motivasi Belajar Dan Hasil Belajar Siswa Pada Materi Kerajaan Hindu. Jurnal Pendidikan Dan IImu Pengetahuan, 20(2), 144-156.

Sugiharto, D. (2018). Meningkatkan Kesegaran Jasmani Melalui Pendekatan Permainan Kecil Siswa SDN Sukomanunggal IV/108 Surabaya, 7, 1-25.

Sugiyono. 2017. Metode Penelitian Bisnis. Bandung: Alfabeta.

Yasin, A. N. (2017). Kelayakan Teoritis Multimedia Interaktif Berbasis Articulate Storyline Materi Sistem Reproduksi Manusia Kelas XI SMA. Berkala IImiah Pendidikan Biologi, 6(2), 169-174. 